\title{
Is There, If Not Virtue, Any Moral Value to Be Found in Payback?
}

\author{
Andrew Flescher 1,2 \\ 1 Department of Family, Population, and Preventive Medicine, Stony Brook University, \\ Stony Brook, NY 11794, USA; Andrew.Flescher@stonybrookmedicine.edu \\ 2 Department of English, Core Faculty in Public Health, Stony Brook University, Stony Brook, NY 11794, USA
}

Received: 12 August 2019; Accepted: 24 December 2019; Published: 6 January 2020

\begin{abstract}
Can payback, punitive action fueled by the desire to hurt an offending aggressor, ever be justified? In Anger and Forgiveness, Martha Nussbaum emphatically answers "no", arguing that payback and the anger on which it is based, even following severe loss, distracts one from pursuing the betterment and loving nature one should be striving to cultivate instead. Timothy Jackson admires Nussbaum's appreciation for such a beautiful spiritual ideal but criticizes her for denying credit to the potential feeler of anger for overcoming the temptation to engage in payback, the initial presence of which is critical for a graceful and triumphant self-transformation. Diana Cates, qualifying Jackson, maintains that we should not assume in payback scenarios that it is suffering that is aimed at, even if the experienced pain of an offender is foreseeable. Granting the worthwhile high road Nussbaum and her respondents seek to travel, one may still ask: is there also a positive case to be made for desiring payback in the extreme case of responding to an egregious offense, i.e., an offense that is violent, paralyzing, and life-altering? Payback will not bring a lost loved one back from the dead, but can it bring oneself back from the dead? This essay explores the merits of this possibility, honing in on the therapeutic aspect of the desire-and occasionally the acting out of the desire-for a victim to pay her aggressor back in kind. Drawing on the work of the Christian realist Reinhold Niebuhr, the Judaic thinker and Holocaust survivor Primo Levi, and the Christian ethicist and feminist Giles Milhaven, I argue that while no moral principle ever ought to be adopted out of retributive action-such action is by definition bereft of virtue-we should nevertheless not dismiss too quickly the notion of there being any moral value in desiring payback, for desiring payback might be an egregiously offended victim's only alternative to the paralysis induced by malice. On this exceptional basis, payback strictly limited to its therapeutic scope may become, for the sake of preserving self-worth, not only tolerable, but a victim's most preferable alternative.
\end{abstract}

Keywords: anger; payback; vengeance; forgiveness; virtue; egregious offense; Martha Nussbaum; Timothy Jackson; Reinhold Niebuhr; Primo Levi; Giles Milhaven

\section{Introduction: The Egregious Offender and the Paralyzed Victim}

Recently, scholars in religious ethics have begun to question whether payback, an action in which a victim hurts, and desires to hurt, her aggressor, is ever justified. In the book which spawned the current debate, Anger and Forgiveness, Martha Nussbaum suggests that choosing to consent to the impulse to participate in payback is irretrievably flawed, for it constitutes a betrayal of a constructive self-betterment in which one should always be engaged, even following horrible loss (Nussbaum 2016). Nussbaum's thesis is that anger and eudaimonia are non-negotiably incompatible. Anger is, in every instance, "normatively problematic" (p. 5), because it is ultimately a gratification based on the false belief that past wrongs may be righted, incurred injuries undone, and damaged selves replenished through the perpetuation of further harms (pp. 22-25). Anger that results in justice may indirectly be 
useful; however, even then, it is not an efficient means of effecting restoration. More likely, feeling angry leads to an obsession with the offender, which has to do neither with justice nor with the injured party feeling better. According to Nussbaum, anger should thus be understood as a trap. One who feels anger is seduced by "magical" thinking that stalls her recovery and changes nothing (p. 34).

Nussbaum's view is partially refuted by Timothy Jackson, who, admiring Nussbaum's appreciation for such a beautiful spiritual ideal (despite her secular orientation), criticizes her for denying credit to the feeler of anger for overcoming the temptation to engage in payback, an initial presence of which is critical for a graceful and triumphant self-transformation (Jackson 2018). According to Jackson, the desire to hurt an offender can be useful, and even rational (pp. 749-50), despite the fact that only faith in Jesus enables real healing through forgiveness. Jackson allows for forms of payback in response to holding a criminal accountable, as is appropriate for all, including criminals, who are accorded dignity and respect (p. 757). Aiming primarily at suffering as a form of restitution in tit-for-tat scenarios, however, is out of bounds for him no less than it is for Nussbaum, even if, with Kant, Jackson holds that "just punishment respects dignity in treating persons as free and responsible" (p. 758). Diana Cates agrees that aiming directly at the suffering of another person as payment for the suffering that he or she previously caused is morally problematic. She argues, moreover, that one can aim at the just punishment of an offender without aiming at the person's suffering per se. Granting the worthwhile high road Nussbaum and her respondents endeavor to travel, the question still stands: is there also a positive case to be made for desiring payback, including willing an offender to suffer in the extreme case of redressing an egregious offense? In this case, the reason to pay an offender back is because it is good for the victim who has been traumatized in a previous attack. Payback is good, because, despite the risk the retributive desirer incurs of becoming undone by the wrathful state she invites, the freeing act of fighting back may be the only activity by which she can come to know herself by an identity other, or rather more, than a victim.

Here, I define an egregious offense as one that rises to the level of violent, paralyzing, and life-altering. A victim of an egregious offense, first of all, is a victim of physical or verbal violence due to which she feels pain and terror as a daily reminder of the shame of past scars. This creates, secondly, a state of mind of being fearful, always, that one will have to endure more pain and terror in the future, precipitating a feeling of helplessness and, soon after, paralysis. Because of this forced "new normal", a victim who suffers an egregious offense is one who will never be the same. Part of my burden in considering the legitimacy of the option of payback for the type of victim I have just described will be to present empirical evidence suggesting that the desire to hurt someone back represents the only practical avenue of escape for a victim who is otherwise stuck. Payback will not bring a lost loved one back from the dead, but might it bring oneself back from the dead? Drawing on the work of the Christian realist Reinhold Niebuhr, the Judaic thinker and Holocaust survivor Primo Levi, and the Christian ethicist and feminist Giles Milhaven, I argue that while no moral principle ought to be adopted out of retributive action—such action is by definition bereft of virtue-we should nevertheless not dismiss the notion of there being any moral value in desiring payback too quickly, for payback might be an egregiously offended victim's only alternative to wallowing in the malaise brought on by suffered malice.

In this exceptional circumstance, I argue that payback may be warranted if the offense is, indeed, shown to be egregious and the payback is measured. By "measured", I mean that the payback is limited strictly to that retributive response that is necessary for a victim's recovery from trauma. While such an evaluation can be determined fully only by the victim herself, there will (and should) also be opportunities for payback to be kept in check by others looking on who can themselves make psychological and ethical assessments. Payback, which, as (Nussbaum 2016, p. 5) specifies and her respondents grant, entails that the offender endure some form of suffering for his or her offense, is neither virtuous nor sustainable. Because of this, payback runs a serious risk of devolving into an aggrandizement of the self. Unchecked retributive action can quickly turn hateful and permanently mar an actor's developing character. If payback is deemed the only course of action that could enable 
a stultified victim to regain agency, then payback might be morally justifiable; however, it ought never to be glorified or celebrated. How might one begin to make the case for the mixed message just expressed, where an action that is possibly justifiable is never one to celebrate or at which to aim if it can be avoided?

By way of analogy, I invoke Reinhold Niebuhr's realpolitik assessment of the necessity of the resort to violence, on dire occasions, to restore the beloved community (Niebuhr 1935, p. 80). We must sometimes dirty our hands to approximate, even as we contradict, a loving, or truly just, polity (Niebuhr 1949, vol. 2, p. 245). I ask whether this communally located historical and political insight can also be applied at the level of the individual in the realm of moral psychology. According to Niebuhr, an anger that fuels violent repulsion of the tyrant is not something in which we have the luxury of not being engaged. Nussbaum, by contrast, assumes we can rise above predicaments of victimhood, arguing that the temptation to anger is to be resisted by keeping in the forefront of one's mind what the loving, constructive object of all action ought to be. For Jackson, that temptation to act on anger, once felt, is to be appreciated for enabling a compassionate forgiveness. One rises above anger and in grace becomes eligible for an agapic love in the faithful tradition of Jesus. Both of these assessments, however, idealistically fail to acknowledge the immobility of one who has had to endure certain forms of intended loss. Insofar as Nussbaum and Jackson, via will and grace-inspired forgiveness, respectively, overestimate the ability of a victim to move past her injury, they blame the one they wish to empower. By contrast, payback, which, in Niebuhr's language, "approximates even as it contradicts" the arrival of a replenished self, may constitute that abdication of virtue that turns out to restore a seriously damaged self's capacity to be virtuous.

Here, the insights of Primo Levi become apt. With the memory of 21 February 1944 in mind, the day on which he and fellow inmates were shipped in overcrowded cattle lorries to Auschwitz, the poet reminds us to be humble and strive for accuracy about a victim's lived experience. One who is sheltered cannot understand what it is like to be exposed and hunted: "Consider whether this is a man who labours in the mud, who knows no peace, who fights for a crust of bread, who dies at a yes or a no" (Levi 1946). En route to a death camp, Levi reminds us, one has no choice but to find a way to survive. Some ordeals are so violent and strike the one enduring them as so experientially horrendous and existentially bewildering that, post-survival, the victim is at a loss to move beyond them. For this person, there is no access to a higher road-no route to forgiveness or to cultivating a forgiving disposition. This is not to say that the victim is not in need of engaging in the purging and uplifting act of forgiving. What would Levi, unlikely theological ally of Niebuhr, have to say to one who desires to be eligible to act virtuously again but does not yet know how?

Giles Milhaven, whose work I consider finally, edges toward a way past this conundrum. Milhaven presents the most straightforward constructive case of which I am aware for an anger that can be "good" and payback that is justified. He offers a way out of a post-traumatic malaise that is prohibited by Nussbaum, presenting the idea that payback, beyond being necessary, can also be a virtuous course of action under circumstances in which the self has been demeaned and injured (Milhaven 1989). I do not go this far. I argue only that, while desiring or even acting on payback is not a virtuous thing to do, it might allow a person to pursue a fulfilling and virtuous life once again. Still, my hope is that Milhaven's reader will seriously consider his provocative thesis that expressions of anger can be part of a healthily lived life. One who is damaged, Milhaven argues, cannot be good for herself or for another. Acting out of anger is thus arguably not just virtuous; it might be the only available virtue-something to embrace in itself. Whether or not he overstates the case, Milhaven's positive characterization of anger is to be commended for illuminating what hopelessness might feel like for a victim.

\section{The Desire to Harm}

Due diligence requires being careful with definitions, and a few distinctions are in order. Save for instances of state-sanctioned justice, "payback", particularly when manifested as an interaction between two parties, refers to a retributive action that not only entails, but crucially depends on, a certain 
desire-anger-which fuels it. It is this desire to hurt that is both dangerous and therapeutically effective with respect to payback. Anger is dangerous because it feeds off of itself, becoming, at once, a source of addiction and a self-fulfilling prophecy for the one who resorts to it. It is not just that anger, due to its nature, is resistant to being kept in check. If not quickly vanquished, it is an emotion that overtakes the one who inhabits it. Anger is all encompassing the instant it appears, eliciting our narcissistic impulses and sensibilities (Nussbaum 2016, p. 29). Once obsessed with anger, it is hard to become unobsessed. Given this risk, it is legitimate to wonder how we might permit ourselves to succumb to anger given how little control we can expect to have when we do. What about such a perilous desire can be that therapeutic?

As I will elucidate when I get to Levi's description of victimhood and Milhaven's account of a victim's unshackling, anger can be forward-looking, surging up out of a cold, dark place and returning one to a state of being in one's life whereupon one can again move into the future. ${ }^{1}$ Anger allows the one damaged to realize that she need not be defined by that damage. The desire to hurt one who has badly hurt you, however raw and unwieldly, demonstrates to oneself that one has strong desires. Feeling this desire allows one to realize that once crushed, one need not stay crushed. Take the case of a victim of domestic abuse, say, of someone who is not only belittled in public, but who in private is also made to feel that she deserves to be punished and embarrassed. Add further to the scenario that this victim is physically brutalized, as victims of abuse commonly are. Over a period of time, she learns that there is nothing she can do to reach her abuser or make him stop. There are hospital visits and the feeling of isolation with which they come. This victim no longer has contact with the outside world. She feels dependent on the one harming her. Now, this scenario fits that of an egregious offense, where one who has incurred violence on a regular basis is perpetually trapped in a state of pain and hopelessness. It is here where the desire to strike back might be of unique use. Anger arises as an emergent opportunity to change a narrative. It emanates from within. It is of a different logic and serves a different end than the coerced, insatiable desire to please and appease one's abuser.

Is such a desire for payback, in fact, effective in the manner in which I am suggesting? Researchers have shown that, by returning pain to the one who caused it, it is possible for victims to reestablish the self-worth they perceive to have been stripped from them. The key lies not in causing others pain, but in showing oneself that one is not powerless (Bies and Tripp 1998; Frijda 1994). Beyond this strategy of replenishment, David S. Chester and C. Nathan DeWall link aggressive responses to ones who have offended us to a sensation that "tips the neural balance towards hedonic reward" post-provocation (Chester and DeWall 2015). In this vein, payback may be recast as a deliberate deflection, diverting attention away from the helplessness in which a victim feels trapped. Some argue for anger's advantageousness on evolutionary grounds (Harmon 2011), with new research leading to the publication of whole volumes making the psychological "case for" payback on the basis of its consonance with human nature (Rosenbaum 2013). Michael McCullough, in support of this naturalism, argues that payback is a distinct behavioral adaptation that evolved to deter malevolent actors from causing future harms and to encourage productive cooperation (McCullough 2008).

I am suggesting that we consider a slightly weaker claim: not that payback is warranted because of our affinity for it, but that, as enacted desire, it can offer certain behavioral advantages, perhaps evolutionarily grounded, which serve as resources for its possessor. If it is true that the belief that payback will help to ease a victim's pain is not about the suffering of another (even if it involves another's suffering) but about empowering the self, then payback might be construed as an enabling act of the imagination (Cates 2018, p. 780; Rippentrop and Cates 2019). In engaging in payback, the objective need not be payback but simply becoming unstuck. Unstuck from what? The paralysis experienced by survivors of trauma is just becoming understood. "Battered Woman Syndrome", now categorized as a subcategory of post-traumatic stress syndrome (Walker 2009), can result in a

1 I am grateful to Diana Cates for this way of describing anger's enabling character. 
"learned helplessness", a psychological immobility according to which a victim is browbeaten into a passive, defeated state. Such a phenomenon is consistent with emerging new evidence pointing to the paralysis many rape victims involuntarily experience during an attack (Möller et al. 2017).

That the desire to fight back might restore lost control to a victim is by itself enough to warrant serious attention. To the extent one tries to harness a power unleashed by anger, however, one handles a delicate powder keg. It is a tricky business, blowing up one's chains but not the world around them. Payback, acted-upon anger, is inherently unstable, threatening to become something more than it appears at first. Payback not kept in check becomes vengeful. For payback not to be vengeful, the retributive actor must manage to dirty one's hands temporarily without, at the same time, doing something irreversibly character damning. As the saying goes, when you dance with the devil, you do not change the devil; the devil changes you.

It is not lost on me that, in the wrong hands, the notion that payback may be the self's only way back to selfhood could be deployed by bad actors to disastrous results. My critic is, first of all, apt to point out that I am building a straw man, for if a person can contemplate payback, he or she probably does not lack self-worth to begin with. ${ }^{2}$ Compounding this complication is the concern that the prescribed therapy will backfire. Payback seems harmful psychologically, precisely because it indulges the ego in ways that are not healthy, arguably exacerbating, rather than productively addressing, the self's damaged state. Third, in the sorts of domestic abuse and Hitler-like cases involving the type of "egregious offense" about which I am worried, it is not the individualized activity of payback but, rather, the social exercise of justice that one should urgently be attempting to achieve. (Albeit, this objection is softened if one considers that justice should not always be taken to be purified of the desire for payback). I have, according to this criticism, unduly elevated the individual above the community and, therefore, the self above the other. How does a deference to the self for the sake of the other, even if temporary, manage not to devolve into an ethic of the primacy of self-regard? Acknowledging the danger that one incurs when payback becomes policy, the critic finally presses: can payback ever be construed as something reliable to utilize on an exceptional basis, limited in scope? Why is it reasonable to think anger could ever be controlled?

I take seriously these concerns about conditionally permitting retributive behavior. Spiritually, I am with Nussbaum and her respondents who hold fast to the normative obligations of a virtuous ideal to act only from a loving, temperate, and constructive disposition. On the other hand, an ideal left unchecked lapses into exploitation. A victim's concrete experience is never fully penetrable. When we are lost to the world, our way back is not necessarily that of others. Among the most exquisite observers of human beings who co-exist in social settings, Nussbaum nevertheless does tend to speak for us all, allowing neither rules for, nor exceptions to, breaches of virtue. How might an alternative balance be forged-one which upholds the twin aspirations of moral development and other-regard, while at the same time taking into less sweeping account a unique victim's perspective? Before attempting an answer, it will be helpful to examine Nussbaum's view in more depth.

\section{Anger, (Proportional) Retribution, Vengeance, and Niebuhr's Christian Realism}

A central assertion in Martha Nussbaum's Anger and Forgiveness is that anger is an emotion that entails a belief that it would not only be permissible, but also good, if the one who injured us somehow suffered for having done so- "good" because it would give something precious back that the injurer took away (Nussbaum 2016, pp. 5-6). This definition of anger puts a significant amount of stock in the "something" which is understood to be replenished by desiring that an injurer pay for causing the injury. That something is assumed to correspond directly to our retributive response, which, for this reason, implies a fallacious sort of thinking that equates our loss with the painful response directed at the one who damaged us (pp. 34,38). Thus, anger is always morally unjustifiable. It attempts to solve a

2 Thanks to Jung Lee for raising this issue. 
problem inefficiently by relying on unsupported faith in a shortcut, which, in fact, has no ability to bring restoration to a pre-injury state of affairs. More problematically, it does so in a manner that takes effort away from the harnessing of legitimate virtuous traits of the self-ones that are importantly disconnected from the injurer and that would do a better job, through independent internal repair on the part of the victim, of making life balanced and sensible again. Responsible individuals ride above the fray of immediacy, eschew distraction, and do not subscribe to a casual and irrational belief that the past can be undone (p. 22). Nussbaum plainly says that she is no Stoic, as nowhere does she dismiss the valuable sentiments of woe, loss, felt suffering, and compassion (p. 40). However, with regard to the impulse to act on base sentiments, i.e., sentiments that cannot be shown to have virtuous content, she does seem stoical. She is so insistent that the victim focus on the process of constructively moving forward, keeping an eye on the ball, that, on my reading, she conveys a near contempt for the one not tough enough to resist a natural desire to strike back at the aggressor. To strike back constitutes a "primitive" petulance because of which a victim should act oppositely, acting with reason, responsibly willing virtue (p. 38).

What Nussbaum, faithfully cosmopolitan, means by "virtues" are the cross-cultural states of character that lead to our moral betterment and happy flourishing. She allows no misplaced psychological substitute for these, whatever their evolutionary benefits (p. 40). For her, there can be no value without virtue. The virtuous actor pursues states of character for their transparent, community affirming, and eudaimoniac qualities. Non-virtuous states lock us in ourselves, isolating us, lacking communal appeal or a community-building telos. Anger, which resists public recognition, is isolating in a way that virtue is not, and besides one exception Nussbaum allows, we should never voluntarily assent to anger's overtaking, or even continuing to affect, us. The exception Nussbaum identifies is a "transitional" anger whose function it is to serve as an alert, jump-starting communal solutions to thwarting the perpetration of future harms. Transitional anger, however, is, upon deeper analysis, also judged to be non-preferable (pp. 6, 35-37). The authentically virtuous person should not need such activation energy to pursue a just social order. Despite that this species of anger, in contrast to its more common irrational variety, allows no retaliatory response, it still reflects a betrayal of the original impulse to love and community build (p. 36). In all instances, we would do better to focus on those things that will improve our well-being, namely, fealty to principle and truth, generosity, love of the other, and a yearning to make our shared world better for its inhabitants (p. 77).

Nussbaum drives home this point at the beginning of Anger and Forgiveness when she invokes the Furies, the goddesses of revenge and retribution of Greek lore depicted in Aeschylus' Oresteia. They are the symbols of "unbridled anger", unable to assimilate to "a working legal system in a society committed to the rule of law" (p. 2). Their only path towards inclusion in Athens-Athena is clear-involves a total relinquishment of identity. Retribution must be replaced in toto with gentleness and temperance. While we still need the Furies-sometimes bad and frightening deterrents are needed as part of a just response- the celebrated lesson of Oresteia, the introduction of justice, mercy, and trust in institutions in civil society, cannot be rendered coherent without its complementary, less appreciated insight, namely, the banishing of any desire for vindictiveness, however tempting such a desire may seem momentarily. The two lessons go together. Justice and truth cannot be granted their full purview while the impulse to vindictiveness persists anywhere.

Is Nussbaum's denunciation of a vindictive desire apropos of a moral universe where powerful parties brutalize weaker ones? According to Nussbaum, justice is not merely the desired end result, but the only legitimate game in town. A bad act cannot result in a virtuous outcome. This is why it is "magical" thinking to believe that revenge can give way to the furtherance of the aims of a civil society. Anger does not just impede but precludes the attainment of the worthy states of character that can directly address undeserved misfortune (p. 35). What of the empirical studies to which I alluded earlier, which suggest that acting out of anger opens a pathway to a once powerless victim to reestablish self-worth? Nussbaum does not seem impressed by the work of social scientists who have studied the utility of payback. She envisions a self that is able, under trying circumstances, to rise 
above these circumstances and conquer the basest human urges. Spurred on by a knowledge of the greater good entailed in building a virtuous character, anger should, and will, dissolve.

Nussbaum does not delve into why she is confident that it is the deprivation of ranking and status, more than anything else, which preoccupies a victim or those wanting to seek justice on the victim's behalf (pp. 20-21). This seems a bit of a leap. Ranking and status are second-order considerations, luxuries from the perspective of one simply desperate to get out of a terrible moment. It is plausible that a victim just wants to be, to live without the memory of what has just happened. Nussbaum offers a prescription for all victims, including the egregiously offended. However, how can she, or anyone, know what a particular victim needs? Not all crimes are the same, much less the victims of crimes. Disallowing the contemplation of anger and the action of payback presupposes comparative analysis in a controlled setting. To know what works and what does not post-trauma, one will presumably have engaged in an examination of victims who have responded this versus that way toward their aggressors, paying attention to relevant differences in their personalities, experimenting with controls and cohort groups and so forth. As Emmanuel Levinas argues, homogenizing generalizations of victims are reductions of others to the self (Levinas 1969, pp. 33-34). Whether payback is ultimately morally justified is, of course, a further determination. However, one can coherently agree with Nussbaum that payback is not virtuous or community building while disputing her assessments about what payback can or cannot do for particular victims, because of which it still may have some value. We need not quarrel over what the high and the low road are to leave open the possibility that the latter may need to be traveled as a last resort.

This claim supposes that there can be value in a pursued course of action short of virtue. What is the difference between value and virtue? "Virtue", certainly, within the Aristotelian tradition, is purposive (Aristotle 1985, pp. 1103a14 ff). This means that the cultivation of the right habits leads to the practitioner's benefit, a virtuous and happy life. Virtuous living involves hard work and practice, training for the good life. Virtue also implies balance (1107a1-3), a stability that can sustain "right" and "fine" living over the long haul. Anger, in contrast, lashes out. Even if an angry disposition could be cultivated and managed, the actor who sought to do so would not be crafting a blueprint for stable or fine living. This is why Nussbaum does not acknowledge value without virtue. A person becomes what she cultivates. To imagine value beyond virtue, one must also be able to act coherently in ways that feel contradictory, to lash out without becoming intemperate. However, this is not how habituation works.

On the other hand, a reason to think that it is not always possible to achieve fine living through the practice of virtue is suggested by Aristotle himself in Nicomachean Ethics where he notes the futility in striving to pursue the good life if one lacks resources to begin with: "Someone may raise this puzzle: 'What do you mean by saying that to become just we must first do just actions and to become temperate we must first do temperate actions? For if we do what is just or temperate, must not we already be just or temperate?'" (1105a18-22). Temperance, the even state of mind that keeps passions and undue impulse in check, is not always available to the one who stands to benefit from it the most. In this case, a stoic answer to what a beleaguered, developing character is supposed to do under adverse circumstances falls on deaf ears. Taking Aristotle's paradox into account, Nussbaum's move to rule out payback leaves the morally acting agent she presumably wants to reach without viable options to move forward, setting up the griever for failure. While there is, of course, value in acting well even if it is not quite from virtue, or when one has not yet attained virtue, virtue is a massive resource and boost. On the other hand, if anger-fueled payback is something that can be resorted to briefly and then let go-if this is possible-it may acquire value in the same fashion other inherently destructive actions do in the service of a longer-term objective. Like the detective who assumes deep cover in an attempt to expose a drug ring, inviting a possible outcome of becoming an addict or something worse, one who decides to resort to anger might also have to betray herself first in order to find herself. While the two cases are not perfectly analogous - the detective does not will someone else to suffer-both the undercover detective and the retributive actor know going in that they are departing from, not edging 
towards, the person they want to be. For reasons they did not choose, the world they inhabit is not as it should be. Both parties must dive down into a mess forced upon them. Neither will likely emerge unscathed, but this in itself does not necessarily preclude a good outcome.

To suggest that anger can have value, however, is not to suggest that it always, or even often, does. At this juncture, we might introduce a distinction between payback and vengeance-that hateful species of the genus of payback in which retribution is desired for a primarily punitive purpose. One who has turned vengeful is focused on the undoing of another, as opposed to payback, which is primarily self-enabling even if an ancillary side-consequence may be that another suffers (Cates 2018, p. 781). Timothy Jackson seems receptive to the possibility that the response of anger to incurred harm is a form of righteous indignation. It can be kept in check and is arguably justified in instances in which the pursuit of betterment involves overcoming formidable obstacles (Jackson 2018, pp. 751-52, 767), even where such indignation takes the form of violent reprisals, as it legitimately does in response to institutional racism. Indeed, only so is Jackson able to note how much more praiseworthy are the actions of historically noteworthy figures such as Martin Luther King, Jr. and Nelson Mandela, who "rose above strict justice to embody a love that is voluntarily beyond the retaliation that it could quite properly claim" (p. 752). Presumably, a notion of "justified moral desert" can take into account proportionately suffered harms incurred by a victim in light of which measured payback can then be intentionally doled out to a perpetrator. One of the purposes of punishment may be to impose suffering that is comparable to, although not necessarily the same as, harms inflicted by the perpetrator. ${ }^{3}$ In other words, the retributive actor acts of out anger and a rational sense of "just desert" at the same time. It is not a perfect science, but it is preferable to forced forgiveness on the part of a victim who has incurred brutal harms that, unaddressed directly, could be considered a form of self-exploitation, precluding the sort of forward-looking attention to the replenishing self of which Nussbaum, on behalf of virtue, is in favor.

Nussbaum, for her part, insists on more than forgiveness, as the existence of forgiveness, which is predicated upon anger, is disallowed. According to Nussbaum, moral betterment should be pursued with no less vigor in the wake of severe personal loss and grieving. Is this realistic or appropriate? Presented with an opportunity to pay back one who has wronged us, few, the best among us, will not feel a need to act retributively. They have the wherewithal to rise above anger. Some Christians may manage to forgive as an "only resort", as a crux of their discipleship. While we might grant, with Nussbaum, that no matter who we are and what we are endowed with, we should strive, when possible to "go the next mile" (Aristotle 1985, pp. 1169a6-8; Flescher 2003), we are also mortals, subjects of finitude, embodied and psychologically constituted beings. There are experiences that many of us cannot "get over" on command. Then, we must dirty our hands, violate discipleship, or cease to be functional. To limit ourselves to not dirtying our hands, in essence, is to exacerbate the unjust destruction visited upon us. Having first failed in pursuing the stoic route, if it is still possible to respond in a proportionately retributive manner, it might be in one's best interests to try.

Let us return to the example raised earlier of the victim of sustained domestic abuse. How can this victim change the arc of her narrative while managing not to acquire a vengeful disposition? While this is not an exact science, the question becomes a little easier to answer upon focusing not on the result of striking back but, rather, on what the act symbolizes. What is essential is that a victim comes to see herself in a different light. This gesture, by which one can surprise oneself, is not calculated but nonetheless presents itself as an alternative to hopelessness. One is again free. Once this is achieved, payback fulfills its object, and there is no longer a need to will the one who caused harm to continue to suffer. Yes, a victim, not necessarily aware of her motives, may have desired to cause pain back, but this was so she could be free again, not for the sake of causing that pain. How a victim reclaims herself by striking back at her aggressor may take several forms. It could entail securing the involvement of

3 My thanks to Jock Reeder for raising these points. 
law enforcement, abandoning someone who is critically dependent on her, striking back physically, or just confiding in a friend. Her striking back may involve actions exercised indirectly or taken from safety, say, disrupting the social capital her abuser had accumulated. In each instance, however, the action taken is about the victim herself, even though it involves someone else. What remains critical is that a victim does not allow her retribution to define her, lest the freeing act become another tool of enslavement. Staving off this inversion is perhaps a lot to ask of someone post-trauma. A good outcome is far from guaranteed. This noted, measured retribution has an ending point, in contrast to vengeance.

A "proportional response" of the sort just considered may not be possible or realistic. Payback could still devolve into vengeance. Nussbaum's position, however, makes no allowance for trial and error. Her interpretation of Aeschylus may be exactly so. In Oresteia, for the Furies to be part of a democracy, they have to transform completely. They cannot be who they once were and be included in the society to come. Regardless of how illustrative this literary example is, however, the well-intended lesson of the Furies becomes another species of armchair philosophy without measuring the frequency with which attempted proportional payback actually does devolve into vengeful self-betrayal. Saying as much does not soften the spirit of Nussbaum's injunction against feeling angry. Rather, it serves as a reminder that an ideal might coexist alongside its lamer approximation, so long as the two are not confused. This conclusion is theologically ambivalent. It is worth endeavoring to be a faithful disciple, but it is also important to have coping strategies when one falls short-a disappointment which does not for a moment mean that that discipleship was any less worth pursuing.

It is with this insight that I invoke the Christian realist, Reinhold Niebuhr. Never one to water down the ideal by confusing it with a concession, Niebuhr nevertheless recognizes that pursuit of an ideal, however possible (even if "impossibly" so), is fraught with the prospect of disappointment. One of Jackson's trenchant critiques of Nussbaum pertains to her mischaracterization of the obligation of forgiveness as a duty of justice rather than charity, which leads to downplaying the privilege and power of that grace, which allows special disciples to do their humanly best (Jackson, 752). Justice, something that is supposed to be applied universally, makes no allowances for those whose shoulders grace has not touched. What of those who strive for a life patterned on Jesus but ultimately fall short of Martin Luther King, Jr.? Here, Niebuhr, in his essay on "Christian Faith and Natural Law", is instructive: "The Biblical conception of man includes three primary terms: (a) he is made in the image of God, (b) he is a creature, and (c) he is a sinner" (Niebuhr 1967, p. 47). Elsewhere, qualifying imago dei in the trying context of violent conflict, he notes it is likely impossible

to establish a justice based upon forgiveness after a war.... The love that is the law of nature is a boundless self-giving. The sin that corrupts its life is a boundless assertion of the self. Between these two forces all kinds of $a d$ hoc restraints may be elaborated and defined. We may call this the natural law. But we had better realize how very tentative it is (p. 54).

Due to sin, we are not only flawed, but also not capable of acting from other than imperfection, a problem further compounded in instances in which we do not know ourselves to be the sinners we are (p. 53). These handicaps likely make forgiveness and other comparable high roads scarcely available if one does not possess the saintly, restorative instincts of a Nelson Mandela.

What consequence should there be for the person, according to this account both victim and sinner, who bears an unspeakable offense? Nussbaum's imperative that we not feel anger, let alone act retributively, arguably holds the sinner to an unreasonable standard of conduct, while Jackson makes room for praising the great moral exemplars for doing the near impossible, but at the expense of leaving out ordinary strivers who have relatively few options for escaping their current hells. In deference to maintaining a preference for the higher road, Niebuhr allows (in the appropriately titled Moral Man and Immoral Society) that individuals, despite being sinners, can sometimes rise to what a demanding non-sinful response entails, specifying that it is in collectives where we are more likely to succumb to baser impulses (Niebuhr 1932). However, as Niebuhr also points out, even in individual settings, we should not become too sentimental. The best among us, such as Gandhi, feature 
a brand of non-violence that also "coerces and destroys" (pp. 231ff, 241-49). There is an incongruity, in other words, in what Nussbaum and Jackson instruct us not to settle for and what even exemplars, who are also sinners, are likely to achieve.

Niebuhr, a realist, is concerned with how to bring about a just society populated by sinners who have less than the resources of Gandhi, for whom the law of agape is not tenable (Niebuhr 1967, p. 33). The strategy of the cross is more often than not counterproductive, a consequence of which is that relying on it leads to the unintentional exploitation of the one who follows it blindly. Love, which both negates and fulfills justice, remains the goal, but love always needs justice, a concession and contradiction of love, in order to be realized (Niebuhr 1935, p. 80). All potentially "moral" individuals, we are also subjects of finitude, marred by our immutable imperfections (Niebuhr 1932). When pure love is overmatched by an exploiter lying in wait, an unloving, forceful response may be called for, so long as it is limited in scope and duration. Niebuhr, a twentieth-century Augustinian, became all too aware of the horrors brought by modern warfare by which killing at a distance became more common and war increasingly became the standard policy, recognizing that the pragmatism and (limited) hopefulness inherent in his "prophetic Christian realism" hinged on the requirement that justice be measured when it checks injustice. When it comes to repelling the tyrant, a just response, which is in the service of love but not itself loving, must be enough to free the oppressed from the clutches of their captivity while still approximating the loving end it seeks (Niebuhr 1949, vol. 2, pp. 245ff).

Likewise, a retributive actor should focus on the task at hand and not let an act of striking back, when called for, become more than a freeing act. It is there only to disrupt immobility. Retribution becomes vengeance when the object of payback turns into the suffering of an oppressor. Then, what is supposed to remain collateral damage becomes the thing directly aimed at, and payback is no longer a measured response. While a justice approximating love corrupts, it also protects. For Niebuhr, no less than for the one for whom measured retribution is temporarily allowable, the love commandment remains in effect at all times. Nothing short of rebuilding and loving engagement can serve as an ending place of a striving self, including the self that is grieving. When we fall short of that ending place, we should not let ourselves off the hook. Instead we should work with, get used to, and learn from disappointment and inadequacy.

\section{A Victim's Options}

How can a measured retribution, the short-term variety that does not become vengeance, enable virtue? In answering, it helps to begin from a place of honesty about the sad, cruel world in which we live. In his seminal catalogue of war and violence in the twentieth century, the bloodiest on human record, historian Jonathan Glover recounts, as part of his sustained argument against the misplaced hope in the Enlightenment Project, a plethora of horrors both true and too graphic to imagine, for example, soldiers stealing babies from their mothers' wombs or taking them from their mothers' arms, throwing them in the air and catching them with their bayonets (Glover 1999, p. 2). These examples he invokes not to shock or torture the reader but, rather, to offer a reality check. This is part of the human story. Summoning more tolerance for cruelty than Ivan Karamazov, who could not get over the unjustified torture of even a single innocent child, we would still not be able to bring into "ultimate harmony" a universe in which those in power violate and destroy helpless innocents (p. 2).

It is important to be clear about what crimes we are and are not able to move past. They are not all the same. "Egregious offense" is the relevant threshold. We have already discussed what rises to the level of "egregious", but it is not an exact science. Thresholds for pain for different victims will be differently experienced. Whatever one's threshold, when exceeded, as when one has been abused to the point of dehumanization, the goal singularly becomes to regain one's lost humanity. Primo Levi's stark and unforgettable description of prisoners crammed into railway cars, being shipped off to the death camps, provides a good example of an experience of "lost humanity" from which it could be hard to move on: 
The SS escort did not hide their amusement at the sight of men and women squatting wherever they could, on the platforms and in the middle of the tracks, and the German passengers openly expressed their disgust: people like this deserve their fate, just look at how they behave. These are not Menschen, human beings, but animals, it's clear as the light of day (Levi 1988, pp. 88-89).

When a human is denied humanity, just whom is supposed to be forgiven and who is to do the forgiving? On the basis of what compelling authority? The point Levi is making seems more urgent than restoring the beloved community from the motive of justice. His unambiguous and bare language confronts his readers in a pedagogical appeal to humble them. To be treated as an animal, stripped of dignity and humanity, stops every other forward-looking process in life. How can we ponder the variety of ways someone who goes through such an experience will respond later in life?

Simon Wiesenthal's classic, The Sunflower, is a true account written to give one the opportunity to participate in this imaginative exercise. Called to the bedside of Karl Seidl, an SS soldier confessing his sins of torture and murder, Wiesenthal is then asked if, as a Jew, he will grant the dying man his request for absolution. An Austrian Holocaust survivor himself, Wiesenthal listened patiently and then left the room in silence (Wiesenthal 1997). Part of the Nazi's revelation included a description of how he and fellow soldiers gunned down a group of 300 Jews who leapt out of windows after the house where they were staying was set on fire.

The second part of The Sunflower contains 53 different responses to Wiesenthal's decision. Jews and non-Jews, including non-Jewish victims of genocide, as well as Albert Speer, the Nazi who famously apologized for the atrocities he facilitated as Hitler's Minister of Armaments and War Production, weighed in on what they would have done. What is striking about these responses is how varied and often ambivalent they are, most acknowledging with self-awareness the extent to which their reactions to Wiesenthal's real-life scenario are governed by their subjective perspectives. Among the non-Jewish responses, however, Father Edward Flannery's stands out as one who attempts a more objective answer. An American priest who devoted much of his career to fighting anti-Semitism, Flannery claimed that by not forgiving Seidl, Wiesenthal became complicit in his sins (Wiesenthal 1997, pp. 136ff). Under different circumstances, we could all find ourselves one day participating in dehumanizing war crimes. Forgiveness, argued Flannery, is an activity of reconnection and restoration regardless of the path one has previously traveled. The universalism in this response is noteworthy, resembling Nussbaum's injunction to "rise above": we all have our part to play in combatting evil, wherever it finds us. Aware of such reactions to Wiesenthal's silence on the part of well-intentioned and compassionate advocates for peace, Primo Levi demurs: "it does not much interest me to know, whether in my depths there lurks a murderer, but I do know I as a guiltless victim am not a murderer" (Levi 1988, p. 48). We cannot know what it is like for someone to go through a violent, unimaginable experience that is not supposed to have happened. We can only know who we are, edging into the future in the manner we are able. We can imagine what we might have done were we in Simon Wiesenthal's shoes, but we cannot know what it was like to be Wiesenthal on the day he had to make a decision.

For Nussbaum, compassion, generosity, and love of the other for the other's sake are among the worthwhile human pursuits that contain cross-cultural appeal if expressed differently across disparate cultures. Albeit no moral Esperanto, the language of virtue does assume shared background beliefs about a "common humanity". By just this reasoning, however, the expectation of virtue is arguably rushed, inappropriate even, in circumstances under which one finds one's dignity under assault. In the example of prisoners being crammed into a train car and shipped to their imminent demise, it is the very presumption of "humanity" that victims are being denied. It therefore seems disingenuous to expect them to rise to their humanly best. If it is being human that confers upon the self the obligations and aspirations attendant to one's membership in the "kingdom of ends", to invoke Kant (Kant 1966, pp. 74, 80ff), one will need one's humanity as a resource. Does membership in the kingdom of ends require one to forgive or to rise above? This is a tall order for one who has been purposefully injured. A victim might still manage to operate from the assumption of a common humanity, despite that it is 
this very assumption that the victim's attacker denies. However, an imperative to forgive or rise above seems misplaced.

What options are realistically available to this victim? Primo Levi asks that we take into account what it is that an aggressor takes from the victim:

Then for the first time we became aware that our language lacks words to express this offence, the demolition of a man. In a moment, with almost prophetic intuition, the reality was revealed to us: we had reached the bottom. It is not possible to sink lower than this; no human condition is more miserable than this, nor could it conceivably be so. Nothing belongs to us anymore; they have taken away our clothes, our shoes, even our hair; if we speak, they will not listen to us, and if they listen, they will not understand. They will even take away our name: and if we want to keep it, we will have to find ourselves the strength to do so, to manage somehow so that behind the name something of us, of us as we were, still remains (Levi 1961, p. 22).

The "demolished" person is the one cast out. Utterly at a loss to understand the suffering one has to endure, once demolished, the way back is by recovering "one's name". In this passage Levi, like Nussbaum, is skeptical of an imagined correspondence between a loss I have suffered due to one who has attacked me and the tangible goods I supposedly will recover with payback. However, according to Levi, "name" is beyond the tangible, beyond matters of ranking and status. It is no less than identity, selfhood. I can never go back to a time before, but, injured and forlorn, I might still be able to recover my identity. Levi describes a world in which "nothing belongs to us anymore". This is an existential threat, not merely a change in circumstances or a loss of things that mattered.

Alternatives to acting out of anger presuppose intact identities by which one can forgive, as Flannery recommends, or resume pursuit of the virtuous life, as Nussbaum instructs. Wiesenthal was silent in the moment he was asked to forgive. His silence leaves open to interpretation the motive for his refusal. It could have been anger. Maybe it was the most he could pull off: not to condemn Seidl further but not to offer him solace or redemption either. Maybe Wiesenthal worried that by speaking in that moment, he would jeopardize his self-integrity, something he might have felt was under the microscope during a time when the names of all Jews were being erased. We cannot know. It is plausible to conclude that his refusal to speak and then write about the experience afterward enabled him to move forward, while, at the time, the alternative, forgiveness, struck him as an unnatural disaffirmation of the genocide in which his conversation partner had participated. As Flannery points out, the choice of forgiveness implies that Wiesenthal's humanity is bound up with that of the dying man before him. Yet, it is humanity that Nazis were attempting to take away. For the dehumanized one without a "name", virtue is out of reach.

Part of what Timothy Jackson identifies in the "paradox of grace" is captured by the reality check made explicit in Levi's memorable recounting: forgiveness is something that cannot be demanded (Jackson 2018, p. 752). If one is a disciple of Jesus, one must, and is positioned to, forgive, despite that from the wronged party's perspective, forgiveness is always a gift, never an instrument or requirement of justice. However, from the perspective of the one who has lost one's name, grace strikes the victim as yet one more demand. Victims qua victims are innocent. Victims and offenders should not be confused. Forgiveness on the part of innocent victims can often be good and virtuous. Forgiveness, as Jackson explicates, is the foregoing of a desire to cause harm (pp. 752-53), whereas its converse, payback, can never be virtuous. However, one cannot insist on forgiveness, which is a matter of love and grace, the access to which is put in jeopardy because of the sustained injury.

One more way to make this point is to consider what the consequence for Wiesenthal would have been had he felt forced or had forced himself to forgive the dying Nazi. What would the psychological effect of such a suppression have been over time? On the other hand, one may wonder: in insisting that a victim and a perpetrator do not have much in common, does Levi go too far? Such thought experiments are instructive, because they call attention to how little we know about what we are 
capable of before we are pushed to the limits of our own humanity. We are not the determiners of how long our memories last or how far they reach. As Margaret Atwood notes, debt lasts beyond even death (Atwood 2008, p. 80). Following trauma, anxiety can linger in perpetuity. For every Mandela who frees himself by unbinding himself from the "chains of vengeance", there are scores unable to escape the truism inherent in Atwood's adage: "Every debt comes with a date on which payment is due" (p. 166). Understanding an egregious offense as an incurred debt, we come to realize how powerless the injured is to move beyond a world that seems forever to have changed. For this person, the pain does not go away. While the timeless injunction "never forget" reminds one who did not experience genocide to pay attention to history, forgetting is never an option for the insider.

If anger is sometimes a last resort, is it not an emotion that can contribute to a virtuous state? Channeling Owen Flanagan, my own answer makes reference to the functional application of an unrealizable ideal. The greyhound hardly catches the rabbit it chases, but it would not run so fast were it not for the rabbit (Flanagan 1991, p. 29). Just because ideals are at the moment unattainable is no justification for their being watered down or confused with a concession. To maintain that Nussbaum or Flanagan require too much of the victim who is not yet past victimization is not to deny the merit in their admonitions, nor to dismiss the resignations about which they are worried in reference to ones who respond out of anger. Anger and the impulse to engage in payback are, at best, necessary evils, suspensions of an appeal to better angels we cannot access anyway. Payback, to repeat, is sometimes a desperate move that is opted for when reason becomes unavailable. What about the critic, however, who assesses responses to an egregious offense from the other side? Before concluding, we will briefly examine one thinker for whom anger is more than a reflection of righteous indignation, more than an unfortunate but necessary concession but, rather, an emotion about which we should not feel so ambivalent.

\section{Good Anger}

According to Giles Milhaven, anger is at the heart of the arsenal of activists and feminists, an intuition and impulse of self-empowerment that should be celebrated, not merely tolerated, because of its ability to promote mutuality, nurturing connection and self-esteem in relations between equals (Milhaven 1989, p. 185). "Vindictive anger", writes Milhaven, "can be extraordinarily valuable when victims are for the first time able to feel vengeful, punitive rage against their oppressor" (p. 185). Milhaven characterizes such moments as "breakthroughs", and he invokes a tradition of feminist literature (Brown 1984; Greenspan 1983; Lorde 1984) in order to call attention to the rehabilitative impact on the self of getting oppressors to stop oppressing and of affirming the freedom, equality, and mutual opportunity that should inhere in any healthy relationship (p. 186). Retribution does not merely serve as a deterrent to malicious behavior; it can be the enabling condition of healthy, respectful living. Writes Milhaven, vindictive anger

can be energy for more constructive passion and action. [It] often rises, without achieving its negative goal, into a broader, positive passion. The individual now wants equality with others whether or not he or she gets it by striking back. The individual now has more inner strength for constructive action. For oppressed individuals anger may be the only energy they have to move into more constructive passion and action (p. 187).

In reference to an abused wife, a contrasting example to Nussbaum's rape victim, Milhaven muses unapologetically:

[This time] she did not feel what she usually did: pity for him or pity for herself or, more recently, despair. She felt, unhidden and unexpected, a strong impulse to grab him by the neck and throw him back down the stairs... There is no question of her doing it. But this spontaneous urge to punish her spouse is not only an appropriate, justified, laudable feeling in itself. Much more importantly ... it is the emergence of a new strength in her for positive 
action she needs to take. It is now possible that she may genuinely desire to take care of herself (p. 188).

Here, there is no tendentiousness, manipulation, or concealed action, only relatable transparency. Vindictive anger, argues Milhaven, can be "constructive passion" or embodied dignity. Far from blocking one from traveling down the passageway leading to a more virtuous life, it is the beginning of that virtuous life. Not one to shy away from the theological bullet one must bite to make a virtue out of anger, Milhaven also grants that while the prize is self-empowerment and positive regard, it is desiring the suffering of the malicious offender that sets the constructive motion in process. Note, the woman in his example need not act on her desire; this scenario features anger without payback. In others, the desire may be actualized. It is the desire itself that is freeing. If such desiring brings us further away from God, it brings us closer too. The alternative is a pity of both self and the other, followed by a settling despair.

Milhaven's approach to conflict entails a refreshing naturalism, not the sort that defers uncritically to ego, but one that entails coherence of emotional response. Whereas stoicism resists the human but less than human impulse in order to reason past "magical" thinking, Milhaven, similar to Atwood, takes into account the long reach of a (in this case, emotional) debt over the one in whose lap it has fallen. The desire to "bite back", as Milhaven puts it, may not restore a disrupted cosmic balance or remove a pain we are experiencing, but it does help us to fight against ongoing sources of pain, the removal of which are tantamount to getting "what we need and want to live our natural life" (Milhaven 1989, p. 171). We have a primal right to this much, to live life as we were meant to live it, powerfully, constructively, and, eventually, virtuously and compassionately.

The question is whether this is enough justification for payback. The one who sees action taken from anger-retribution - as a last resort and never as a virtue can take issue with Milhaven by locating the priority he gives to the self over the other. Other-regard is not Milhaven's highest priority, and critics are bound to object to his value-ordering on both religious and non-religious grounds. Milhaven's elevation of "what we need and what we want to live our natural life" over agapic living, when the two come into conflict, is arguably problematic even if we grant that retribution optimizes restoring functionality to a victim. In Good Anger, Milhaven admits that the pursuit of the "natural life" includes anger no less than the hedonic pleasures of eating, drinking, sleep, and sex (p. 171). The more the objects of Milhaven's categories come to light, the less apropos they seem to a life governed by the imperatives attendant to the second love commandment. By contrast, the first thing agapists, including non-Christian ones, such as Emmanuel Levinas, are wont to point out is the asymmetry between other and self, where the former has unqualified, non-negotiable, and originary priority (Levinas 1974). Payback as a part of what is normal in life might be consistent with the life philosophy of Jack London's brutish sea captain Wolf Larsen, where "weakness is wrong" (London 1991). It irrevocably, not just temporarily, contradicts a life in which virtue is cast as paramount.

By the same token, reading Milhaven is instructive insofar as it makes the victim's experience one of primary importance, a refreshing contrast to rule following based on top-down normative visioning. In appreciating Milhaven's naturalized theology, one realizes how badly needed are more studies devoted to understanding not just the evolutionary or psychologically adaptive uses of retributive behavior, but also to identifying the limits to emotional and moral development post-trauma. We need to hear more from scientists about why retribution is a pragmatic, therapeutic last resort. At the moment, it cannot be categorically ruled out.

\section{A Conclusion in Which I Am, at Most, Weakly Confident}

Upon learning of my writing this article, intelligent people for whom I have great respect appealed to me to think about what might happen were my conclusion to fall in the wrong hands. How many atrocities have historically been excused under the banner of tough love? How many moral lapses have been cast aside in deference to a "necessity" posing as self-evident naturalism? These are valid concerns. When a high road is identified, ethicists should not go out of their way to discover a lower 
one. As critics of the reluctant recourse to violence have long pointed out, we can be awfully sloppy about asserting when the time for the "last resort" in fact arrives, whether, as in the case of war and reconciliation, this involves repelling the aggressor with violent force or, as in the case of dealing with an egregious offense, responding to an individual aggressor retributively. As Kant observes, it is hard work to be self-aware enough to distinguish the lust to harm the one who has hurt us from any more justifiable actionable impulse. When someone injures me, can I be sure to trust my motives from that point on? Are there not consequences to the other-regarding moral universe I hope to build when I do not act other-regardingly, frustrated as I may be trying to live up to this demand?

Because of these concerns, I am not overly confident in the conclusion to which I seem to have arrived: that under conditions of an egregious offense, it may be permissible temporarily to issue a proportional retributive response and that this response, even if not virtuous itself, may have moral value, because it makes one again eligible to pursue the virtuous life. Primo Levi impresses upon us the importance of listening to what a victim has to say. However, as victims, I am not so sure we can ever know that payback represents our only alternative to helplessness and inaction. I also worry that the self's potential recovery should be permitted to take precedence over agapic living when the two objectives come into conflict.

It is at this point in the dialogical speculation where it becomes important to take the perspective of all of the relevant parties under consideration. If we should be cautious about deferring absolutely to the concrete victim who has suffered, we do have, at least, sound grounds on which to worry that Nussbaum has not listened closely enough to them. As we learn about the worst that victims of unspeakable crimes can experience, we should lose any confidence we might have had in their freedom of will to overcome what they had to endure.

In Anger and Forgiveness, Nussbaum makes clear that she is unwilling to lose this confidence in the human spirit. This determination stands in somewhat of a contrast to the observation expressed in The Fragility of Goodness, where she characterizes the pursuit of virtue and the good itself as "fragile": ephemeral and elusive, every bit worthy of our ambition, if they cannot always be counted upon to be attained easily (Nussbaum 1986). In other words, we are finite, striving creatures, bound to experience disappointment more than success, but no less noble for our failures. We are neither beasts nor gods, but fallible mortals. The observation is hopeful, betting on a human being's ability to strive for betterment despite the more common experiences of loss and frustration. For the one who is wounded and damaged, the feeling of anger and the response of payback might be the best one can do at the moment, implicitly hoping there are moments beyond in which dignity, composure, and the pursuit of virtue are no longer quite so out of reach.

Funding: This research received no external funding.

Acknowledgments: I want to thank Diana Cates, Jung Lee, Jock Reeder, Alistair Rogers, Jack Coulehan, and the anonymous reviewers of Religions for their invaluable feedback and reflective criticism.

Conflicts of Interest: I have no conflict of interest.

\section{References}

Aristotle. 1985. Nicomachean Ethics. Translated by Terence Irwin. Indianapolis: Hackett Publishing.

Atwood, Margaret. 2008. Payback: Debt and the Shadow Side of Wealth. Toronto: Anansi Press.

Bies, Robert J., and Thomas M. Tripp. 1998. Revenge in organizations: The good, the bad, and the ugly. In Dysfunctional Behavior in Organizations. Edited by Ricky W. Griffin, Anne O'Leary-Kelly and Judith Collins. Stamford: JAI Press, vol. 1, pp. 49-67.

Brown, Karen McCarthy. 1984. Why Women Need the God of War. In Women's Spirit Bonding. Edited by Janet Kalven and Mary I. Buckley. New York: Pilgrim Press, pp. 190-201.

Cates, Diana Fritz. 2018. You Deserve to Suffer for What You Did. Journal of Religious Ethics 46: 771-82. [CrossRef]

Chester, David S., and C. Nathan DeWall. 2015. The pleasure of revenge: Retaliatory aggression arises from a neural imbalance toward reward. Social Cognitive and Affective Neuroscience 11: 1173-82. [CrossRef] [PubMed] 
Flanagan, Owen. 1991. Varieties of Moral Personality: Ethics and Psychological Realism. Cambridge: Harvard University Press.

Flescher, Andrew. 2003. Heroes, Saints, and Ordinary Morality. Washington, DC: Georgetown University Press. Frijda, Nico H. 1994. The lex talionis: On vengeance. In Emotions: Essays on Emotion Theory. Edited by Stephanie H. M. van Goozen, Nanne E. Van de Poll and Joseph A. Sergeant. Hillsdale: Lawrence Erlbaum Associates, pp. 263-89.

Glover, Jonathan. 1999. Humanity: A Moral History of the Twentieth Century. New Haven: Yale University Press. Greenspan, Miriam. 1983. A New Approach to Women and Therapy. New York: McGraw-Hill Press.

Harmon, Katherine. 2011. Does Revenge Serve an Evolutionary Purpose? Scientific American. May 4. Available online: https://www.scientificamerican.com/article/revenge-evolution/ (accessed on 3 January 2020).

Jackson, Timothy P. 2018. Not Far from The Kingdom: Martha Nussbaum On Anger and Forgiveness. Journal of Religious Ethics 46: 749-70. [CrossRef]

Kant, Immanuel. 1966. The Moral Law: Kant's 'Groundwork of the Metaphysic of Morals'. Translated by Herbert James Paton. London: Hutchinson and Company, Ltd.

Levi, Primo. 1946. Shema. Translated by Ruth Feldman, and Brian Swann. London: Menard Press, Available online: http://famouspoetsandpoems.com/poets/primo_levi/poems/3719 (accessed on 3 January 2020).

Levi, Primo. 1961. Survival in Auschwitz: The Nazi Assault on Humanity. Translated by Stuart Wolf. New York: Collier Books, Originally Published in 1947. If This is a Man. Turin: Da Silva.

Levi, Primo. 1988. The Drowned and the Saved. Translated by Raymond Rosenthal. New York: Simon \& Schuster.

Levinas, Emmanuel. 1969. Totality and Infinity: An Essay on Exteriority. Translated by Alphonso Lingis. Pittsburgh: Duquesne University Press.

Levinas, Emmanuel. 1974. Otherwise than Being or Beyond Essence. Translated by Alphonso Lingis. The Hague: Martinus Nijhoff.

London, Jack. 1991. The Sea Wolf. New York: Bantam Books.

Lorde, Audrey. 1984. The Uses of Anger: Women Responding to Racism. In Sister Outsider: Essays and Speeches. Berkeley: The Crossing Press, pp. 124-33.

McCullough, M. E. 2008. Beyond Revenge. San Francisco: Jossey-Bass.

Milhaven, Giles. 1989. Good Anger. Kansas City: Sheed \& Ward.

Möller, Anna, Hans Peter Söndergaard, and Lotti Helström. 2017. Tonic immobility during sexual assault-A common reaction predicting post-traumatic stress disorder and severe depression. Acta Obstetricia et Gynecologica Scandinavica 96: 932-38. [CrossRef] [PubMed]

Niebuhr, Reinhold. 1932. Moral Man and Immoral Society. New York: Charles Scribner's Sons.

Niebuhr, Reinhold. 1935. An Interpretation of Christian Ethics. San Francisco: Harper \& Row.

Niebuhr, Reinhold. 1949. The Nature and Destiny of Man: A Christian Interpretation. New York: Charles Scribner's Sons, vol. 2.

Niebuhr, Reinhold. 1967. Love and Justice: Selections from the Shorter Writings of Reinhold Niebuhr. Edited by D. B. Robertson. New York: Meridian Books.

Nussbaum, Martha. 1986. The Fragility of Goodness: Luck and Ethics in Greek Tragedy and Philosophy. Cambridge: Cambridge University Press.

Nussbaum, Martha. 2016. Anger and Forgiveness: Resentment, Generosity, Justice. Oxford: Oxford University Press. Rippentrop, Jan Schnell, and Diana Fritz Cates. 2019. Rethinking Anger as a Desire for Payback: A Modified Thomistic View. Religions 10: 618. [CrossRef]

Rosenbaum, Thane. 2013. Payback: The Case for Revenge. Chicago: University of Chicago Press.

Walker, L. E. 2009. The Battered Woman Syndrome, 3rd ed. New York: Springer Publishing Company.

Wiesenthal, Simon. 1997. The Sunflower: On the Possibilities and Limits of Forgiveness. In Mazal Holocaust Collection, 2nd ed. Edited by Harry J. Fetterman Cargas and V. Bonny. New York: Schocken Books.

(C) 2020 by the author. Licensee MDPI, Basel, Switzerland. This article is an open access article distributed under the terms and conditions of the Creative Commons Attribution (CC BY) license (http://creativecommons.org/licenses/by/4.0/). 